\title{
perifèria
}

Número 7, diciembre 2007

www. periferia. name

\section{La sustentabilitat de les plantes medicinals a les muntanyes de Karandamalai, Tamil Nadu-I ndia}

\author{
Judith Saus Moreno ${ }^{1}$ - Departament d'Antropologia Social i Cultural (UAB)
}

\section{Resum}

En els darrers anys, el coneixement i ús dels efectes beneficiosos de les plantes medicinals s'ha estès de manera global als països del Nord. Les companyies farmacèutiques $\mathrm{i}$ de productes naturals donen unes condicions comercials pèssimes als recol-lectors rurals, intensificant així la sobreexplotació del medi i de les persones que hi habiten (Shiva, 1989).

En aquest article examinem una comunitat rural del Sud de la India que depèn intensament dels recursos naturals del bosc, i que té com a activitat bàsica de subsistència la recollida i comercialització de plantes medicinals. Aquesta comunitat des de fa més de 15 anys comercialitza plantes medicinals a través del mercat, amb unes pobres condicions comercials. Des de fa cinc anys una Organització No Governamental per al desenvolupament (ONGD) india, va entrar al poble per oferir un canal de comercialització alternatiu al mercat, a través d'una empresa cooperativa formada per grups de recol-lectors rurals de diversos municipis de l'àrea.

Dins aquest context analitzen com dos patrons diferents de recol.lecció i comercialització de plantes medicinals- i.e., mercat i cooperatives fomentades per ONGD- afecten a la sustentabilitat del bosc (sustentabilitat ecològica) i a la dels seus habitants (sustentabilitat econòmica, social, i cultural).

Palabras clave: sustentabilidad, conocimiento ecológico tradicional, ONGD, India.

\section{Abstract}

In the last decades the knowledge and use of the benefits of medicinal plants had spread all over the world. Pharmaceutical and natural product companies give dreadful commercial conditions for the rural collectors, which imply an overexploitation of the ecosystem and of their inhabitants (Shiva,1989).

In this article I examine a rural community in South India which depends on the natural resources for livelihood. The gathering and commercialization of medicinal plants is the main activity in the village. For the last 15 years this community has been selling medicinal plants to traders from local markets, having poor commercial conditions. Since 2001 an Indian NGO have been promoting gatherers groups, giving them an alternative commercialization channel, with a cooperative enterprise formed by rural gatherers groups from nearer villages.

In this context I argue about the relation that the gathering of medicinal plants has with the sustainability of the forest (ecological sustainability) and of its inhabitants (economical, social and, cultural sustainability).

Keywords: sustainability, TEK, NGO, India.

\footnotetext{
${ }^{1}$ Judith Saus Moreno: jinsklins@yhaoo.es.
} 


\section{perifèria}

Número 7, diciembre 2007

www. periferia. name

\section{I ntroducció}

En els darrers anys, el coneixement i ús dels efectes beneficiosos de les plantes medicinals s'ha estès al món comercial. Les companyies farmacèutiques i de productes naturals donen unes condicions comercials pèssimes als recol-lectors rurals, intensificant així la sobreexplotació del medi i de les persones que hi habiten (Shiva, 1989).

Diversos estudis de cas -Kuhnlein i Turner (1991); Shiva (1989, 1993); Sharachchandra Lelé i Rao (1996); Uma et al (1996)- han demostrat que la comercialització de plantes medicinals pot tenir efectes devastadors per l'ecosistema i per la subsistència local, si l'activitat es porta a terme sense l'adequat monitoratge dels recursos naturals i el foment de pràctiques i tècniques de recol.lecció sostenibles. Tot i aquests problemes potencials, la recollida i comercialització de plantes medicinals ha estat proposada com una activitat econòmica que pot millorar les condicions de vida de les comunitats indígenes i rurals, sense malmetre el seu ecosistema (Sinha i Bawa, 2002).

En aquest article es descriuen les formes de subsistència d'una petita comunitat de la casta Valaiyar del sud de la Índia, Manthakulathupatti (MKP), situada al peu de les muntanyes de Karandamalai a Tamil Nadu. Des de fa més de 500 anys els habitants de MKP depenien totalment dels recursos del bosc i de l'agricultura de secà per a la seva subsistència. Utilitzaven les plantes medicinals per l'autosanació dins el sistema tradicional de medicina Siddha ${ }^{2}$, tenint per tant un extens coneixement local sobre les plantes medicinals i els seus remeis associats.

En els últims 50 anys MKP ha sofert importants canvis ecològics i socials. Diferents informants ens expliquen que una estació de pluges del monsó s'ha reduït de manera progressiva, condicionant les activitats tradicionals de subsistència dels seus habitants. Aquests canvis ecològics van propiciar l'entrada de noves activitats econòmiques, incloent la comercialització de plantes medicinals, el focus d'aquest article.

\footnotetext{
2 Sidha Medicine: sistema de salut tradicional del Sud de la Índia, basat en principis d'espècies naturals per a la prevenció i sanació de malalties (Singh i Jain, 2003).
} 


\section{perifèria}

Número 7, diciembre 2007

www. periferia. name

A partir dels anys 90, van començar a arribar a MKP diferents comerciants de plantes medicinals de Dindigul (capital del Districte). La relació preu/treball era molt desfavorable per als recol-lectors, però aquests ho acceptaven per poder sobreviure. L'oportunitat de comercialitzar plantes medicinals va incentivar la recol.lecció de certes espècies, que amb el temps s'estan sobreexplotaant a Karandamalai.

Des del 2001 una ONGD de Madurai, Covenant Centre for Development $(C C D)^{3}$, va arribar a MKP. CCD vol impulsar el desenvolupament sostenible del poble a través de grups cooperatius de plantes medicinals, oferint unes condicions comercials més favorables que el mercat i intentant promoure els sistemes locals de salut i la conservació de les plantes medicinals.

En aquest context la comercialització de plantes medicinals s'ha convertit en la principal forma de subsistència del poble, i per tant té un important impacte sobre l'ecosistema i els seus habitants. En l'article s'analitza aquest l'impacte de la comercialització de plantes medicinals en dos esquemes comercials: la comercialització via mercat i la comercialització cooperativa a través de la ONGD CCD.

Veurem com els dos patrons de recol.lecció i comercialització de plantes medicinals poden afectar la sustentabilitat del bosc (sustentabilitat ecològica) i als Valaiyars que hi habiten (sustentabilitat econòmica, social, i cultural).

Creiem necessari un nou punt de vista teòric en l'anàlisi dels sistemes de desenvolupament rural, deixant enrere els pressupostos economicistes que incorpora el desenvolupament sostenible per aproximar-nos des de l'antropologia del desenvolupament a la sustentabilitat. Presentem doncs un nou concepte on els factors socials, culturals, són claus per entendre els sistemes de subsistència de les comunitats locals.

${ }^{3}<$ http: //www.ccd.org.in> 


\section{perifèria}

Número 7, diciembre 2007

www. periferia. name

\section{Antecedents Teòrics}

A partir dels 90 l'Antropologia aborda el desenvolupament des de dues perspectives aparentment oposades, ja que fins aleshores la perspectiva dominant era la visió economicista i de reproducció del sistema neoliberal per a desenvolupar els pobles més pobres. En aquest context les dues grans corrents antropològiques sobre el desenvolupament són:

- Antropologia per al desenvolupament (Development Anthropology) liderada por autores como Cernea (1995) i Horowitz (1996), on es valora la implicació de l'antropòleg com a mediador cultural entre les agències de desenvolupament i els poble que es pretén desenvolupar. Aquesta antropologia considera clau la incorporació dels factors culturals per al desenvolupament dels pobres, però no es qüestiona si el model dominant de desenvolupament capitalista que fomenta la cooperació internacional, per molt basat en la cultura local que estigui, pugui comportar greus conseqüències i desestabilitzacions en les societats locals.

- Antropologia del desenvolupament (Anthropology of Development), liderada por Apffel-Marglin and Marglin (1990), Breton (1999, 2001, 2005), Escobar (1984, 1985, 1988, 1995, 1998, 2002), Esteva (1987,1993,2000), Fals Borda (1988), Ferguson (1990), Rahnema (1988), Sachs (1993), Stavenhagen (1971), Viola (2000), entre altres, es basa en el paradigma postmodern, on es critica la mateixa concepció de desenvolupament argumentant que les relacions de poder que s'estableixen entre agències i desenvolupats són asimètriques, que les intencions i les conseqüències dels projectes de cooperació internacional són més retòriques que reals.

Aquests autors proposen un canvi de paradigma, tot i que en alguns casos els seus objectius siguin més crítics que constructius. Personalment, em posiciono en aquesta corrent teòrica com a base del canvi paradigmàtic necessari, proposant el concepte de sustentabilitat com a alternativa al desenvolupament sostenible. Aquest nou concepte representa una nova forma d'entendre les relacions entre els sers humans i el seu ecosistema, lluny de les relacions capitalistes i de sobreexplotació dels recursos 


\section{perifèria}

Número 7, diciembre 2007

www.periferia. name

fomentades des de l'aparell del desenvolupament ${ }^{4}$. La sustentabilitat pretén entendre de forma més natural i integrada la subsistència de les societats dins del seu ecosistema, tenint com a eix central l'autonomia i la preservació de la cultura local.

Desenvolupament sostenible i Sustentabilitat

El concepte de desenvolupament sostenible cobra força a finals dels anys 80 a partir de l'informe Brundtland "Our Common Future" (1987), encarregat per la Comissió de Mediambient del Banc Mundial i tota la reflexió crítica que aquest va contribuir en les successives cimeres i trobades internacionals ${ }^{5}$. A l'informe Brundtland es defineix el desenvolupament sostenible com:

El desarrollo sostenible es el desarrollo que satisface las necesidades de la generación presente sin comprometer la capacidad de generaciones futuras para satisfacer sus propias necesidades.

El concepto de "necesidades", en particular las necesidades esenciales de los pobres, a las que se debería otorgar prioridad preponderante;

La idea de limitaciones impuestas por el estado de la tecnología y la organización social entre las capacidades del medio ambiente para satisfacer las necesidades presentes y futuras. (1987:67)

Segons aquesta definició, el desenvolupament sostenible pretén fer possible les activitats econòmiques, ambientals, i socials perdurables en el temps. La integració

4 Parafrasejant a Arturo Escobar i a Victor Bretón en les seves múltiples publicacions. L'aparell del desenvolupament són el conjunt d'institucions internacionals i nacionals- des del Banc Mundial i el Fons Monetari Internacional a les ONGD- que actuen com agents per al desenvolupament dels països denominats del Sud o de la Perifèria. Aquestes institucions reprodueixen el sistema de desenvolupament capitalita i de mercat com a fórmula per reduir la pobresa i les desigualtats socials.

5 Altres cimeres on s'ha abordat el desenvolupament sostenible són: Conferència Internacional sobre la Biosfera (París 1968); Fundació del Club de Roma (1969), Conferència sobre el medi humà de les Nacions Unides celebrada a Estocolm (1972), Estratègia mundial per a la conservació UICN (1980); Comissió Mundial sobre el Medi Ambient i el Desenvolupament convocada per Nacions Unides (1984). Informe "El Nostre Futur Comú", més conegut com Informe Brundtland (1987); Estratègia mundial per a la conservació (1990); Cimera de la Terra. Conferència de les Nacions Unides per al Medi Ambient i el Desenvolupament celebrada a Rio de Janeiro (1992); Agenda 21 realitzat per la ONU i es basa en un pla d'acció amb l'objectiu de fer realitat els acords presos a la Cimera de la Terra; Publicació de la Carta de la Terra (1994); La Carta de la Terra es dota d'una comissió de seguiment i d'un Secretariat establert a Costa Rica (1997); 1o Fòrum Social Mundial a Porto Alegre (Brasil, 2001); 2o Fòrum Social Mundial a Porto Alegre (Brasil, 2002); Cimera Mundial sobre el Desenvolupament Sostenible (Rio $+10,2002$ ) celebrada a Johannesburg. S'evidencien els resultats limitats de l'aplicació de l'Agenda 21 i s'assumeix el compromís de millorar i enfortir la governabilitat en tots els aspectes per aconseguir l'aplicació efectiva del Programa 21, els objectius de desenvolupament del Mil-lenni i el Pla d'aplicació de les decisions de la Cimera; 3 Fòrum Social Mundial a Porto Alegre (Brasil, 2003); Diàlegs de la Terra (Barcelona, Espanta, 2004). 4o Fòrum Social Mundial a Bombai (Índia, 2004). Finalment els Objectius del Millenni declarats per les Nacions Unides marquen els objectius internacionals de cooperació i desenvolupament a assolir al 2015. Sembla però que tot i aquestes cimeres els objectius del mil·enni estan lluny d'aconseguir-se. 


\section{perifèria}

Número 7, diciembre 2007

www. periferia. name

d'aquestes tres vessants del desenvolupament incorpora la distribució equitativa de la riquesa, l'ús dels recursos naturals per sota de la seva capacitat de càrrega, i I'habitabilitat del planeta com a principis operatius. Principis que en la situació ambiental global que ens trobem avui, semblen no adaptar-se massa a la realitat.

A l'informe Brundtland també es destaca la importància del reconeixement d'un interès comú i d'equitat, per a l'èxit del desenvolupament sostenible. Altre cop donada l'estructura inequitativa de l'accés i possessió dels recursos del sistema neoliberal, aquest sembla difícil d'aconseguir-se tan a nivell polític com econòmic. El desenvolupament sostenible tot i certa dimensió crítica, no aporta la pressió necessària per el canvi paradigmàtic i polític que es planteja en els seus objectius inicials.

Segons Sachs (1993), Braidotti et al (1994), Robertson (1992) el concepte de desenvolupament sostenible, utilitzat des dels anys 80 , s'ha de repensar en base a l'alternativa neoliberal dominant. Aquests autors proposen un nou concepte on es tinguin presents en primer terme als beneficiaris dels plans de desenvolupament, posant en dubte fins hi tot la necessitat de realitzar-hi intervencions. El terme que s'utilitza des d'aquesta perspectiva crítica és el de sustentabilitat (sustainability), que pren caràcter d'autonomia i cosmovisió dels propis membres per escollir quin tipus, forma i planificació de desenvolupament es necessita.

En resposta a la inadequació dels programes implementats en mires al desenvolupament sostenible, al llarg dels anys 1990 i 2000, diferents moviments socials d'Amèrica llatina, Àsia i fins hi tot Europa, s'han aixecat per lluitar en la defensa de les seves terres, pel dret a l'autodeterminació i pel dret a decidir quin desenvolupament es vol. Els moviments per la defensa del territori de les Comunitats negres del Pacífic Colombià exposades per Escobar (1998), o els aixecaments populars indígenes ocorreguts a Equador durant els anys 90 i el 2000, o el moviment de dones Chipcko al Nord de la Índia exposat per Shiva (1989), són alguns dels exemples de la Iluita per un desenvolupament propi basat en una altre concepció de les relacions entre natura i societat, que les plantejades des dels països suposadament "desenvolupats".

Aquests grups reivindiquen l'autonomia de gestió i la propietat de la terra, com a punt inicial per la millora de les seves condicions de vida i la base de la seva política en la gestió natural del recursos, tenint presents la seva història, cosmologia i cultura local. 


\section{perifèria}

Número 7, diciembre 2007

www. periferia. name

Aquests estudis exposen a més, la necessitat de control del desenvolupament a través de les mans de les comunitats locals, amb una participació directa i activa en la política i economia.

Des d'una altre perspectiva l'Ecologia política amb autors com Bryant (1992), Breton (1999), Bedoya y Martínez (2000), Painter y Durham (1995), Escobar (1998), entre d'altres, també incorpora aquesta visió crítica i ofereix un marc d'anàlisi molt més complex, gràcies a la inclusió de factors com les relacions internacionals de dependència, la dinàmica del capitalisme global, les polítiques estatals, o l'estructura socio-econòmica local, que condicionen fortament la sustentabilitat dels pobles.

Finalment la visió integradora que ens ofereix l'ecofeminisme de Mies (1998) i Shiva (1989, 1993, 1998 i 2005), on les relacions entre els sistemes de subsistència i els recursos naturals han de dependre de les comunitats locals en una autèntica "democràcia participativa", ens denoten la importància d'analitzar les relacions socials i culturals des d'una altre perspectiva, on el medi natural en sigui l'eix central.

Aquestes perspectives les considero bàsiques per analitzar el que s'entén per sustentabilitat i sobretot per veure quina perspectiva en tenen els pobles titllats de "subdesenvolupats".

A títol propi i inspirats en la definició d'Escobar (1998: 19), proposo la següent definició per operacionalitzar la sustentabilitat:

La sustentabilitat entesa com un procés de canvi que integri processos culturals de significació i identitat, processos ecològics d'un ecosistema canviant, processos socials d'autonomia i participació i processos tecno-econòmics d'utilització dels recursos que permetin la subsistència de la vida actual i futura. La sustentabilitat s'ha d'entendre com l'equilibri entre aquests processos dinàmics, des del nivell local al global, amb l'ecosistema com a eix central. La sustentabilitat ha de respondre doncs, de manera integral i multidimensional a les pràctiques d'apropiacions efectives dels ecosistemes. 


\section{perifèria}

Número 7, diciembre 2007

www. periferia. name

A nivell metodològic afegir breument les tècniques emprades al llarg del treball de Camp durant els 3 mesos d'estada a MKP (Gener-Abril 2007) ${ }^{6}$. En primer terme l'observació participant ha estat l'eix de tot el treball. El primer mes i mig es van aplicar tècniques més qualitatives com entrevistes informals, grups focals als grups cooperatius i tècniques participatives amb tot el poble. En la segona fase de la recerca per tal d'aproximar-nos a l'anàlisi de la sustentabilitat, es van utilitzar entrevistes semiestructurades i la tècnica de xarxes socials, analitzant les relacions laborals en les diferents activitats de subsistència a MKP, entre elles la recollida i comercialització de plantes medicinals. Finalment l'extensa bibliografia local amb estudis de camp a la zona i a nivell nacional, ha facilitat l'anàlisi i les primeres aproximacions a la sustentabilitat, en un període tan breu de camp.

\section{Contextualització del cas d'estudi}

\section{Els Valaiyars a Karandamalai}

Manthakulathupatti (MKP) és un poble situat als peus de les muntanyes de Karadamalai al centre de Tamil Nadu, format únicament per gent de la casta Valaiyar. Segons el Govern Indi, la casta Valaiyar s'ubica dins les Most Backward Classes, la casta més baixa a la Índia per sobre dels intocables. Les Most Backward Classes representen comunitats camperoles i rurals.

Històricament els Valaiyars s'ubicaven al Nord de Tamil Nadu, vivint a les fèrtils planícies del riu Cauvery. Degut a la migració interna diferents pobles, es van anar expandint al llarg de tot Tamil Nadu, i avui dia els Valaiyars es troben distribuïts entre els estats de Tamil Nadu, Karnataka i Andhra Pradesh. Segons ens expliquen diferents informants de MKP, es creu que els Valaiyars van emigrar a les terres de Karandamalai fa més de 500 anys, subsistint gràcies a l'agricultura de secà i dels recursos naturals que oferia el bosc.

L'any 1977, un total de 6.518 hectàrees de l'àrea de Karandamalai va ser declarada zona de "boscos reservats" pel Departament Forestal de Tamil Nadu. La principal

\footnotetext{
${ }^{6}$ Treball de Camp finançat gràcies a una beca del Laboratori d'Etnoecologia a I'ICTA, liderat per la Dra. Victòria Reyes-Garcia sota el marc (MIRG-CT-2006-036532).
} 


\section{perifèria}

Número 7, diciembre 2007

www. periferia. name

riquesa biològica dels boscos de Karandamalai es troba en la seva gran biodiversitat en plantes medicinals i altres NFTP ${ }^{7}$ (més de 300 espècies NFTP i més de 20 espècies arbòries, segons Saravanan (2006:23).

Les regulacions establertes en els "boscos reservats" de Karandamalai es basen en la prohibició de talar arbres, la caça, regulacions sobre l'extracció dels productes naturals del bosc (NFTP) per la seva comercialització, delimitació de la zona de pastoreig i de la recollida de fusta. Al mateix temps el Departament Forestal també realitza replantacions $\mathrm{i}$ altres gestions forestals per tal de preservar la biodiversitat i la qualitat de l'ecosistema. Aquestes actuacions han condicionat la capacitat de subsistència dels habitants de MKP i altres pobles de la zona, limitant el nombre de camps de cultiu i l'extracció de NFTP dels boscos de Karandamalai.

\section{Manthakulathupatti, un poble Valaiyar}

MKP es troba en el Districte de Dindigul, concretament a $60 \mathrm{~km}$ de Madurai i a $14 \mathrm{~km}$ de Natham, capital del taluk ${ }^{8}$. Vegem-ho en el següents mapes:

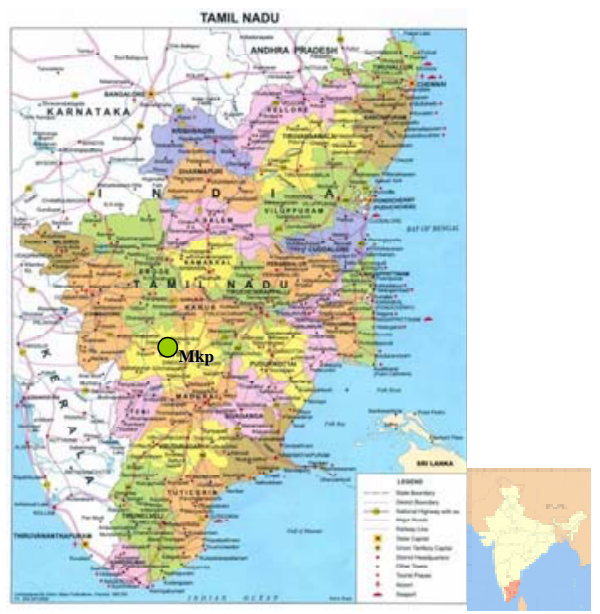

I I-Iustració 1. Mapa de Tamil Nadu

Font: <http://www.travelmadeeasy.in/map-tamilnadu.jpg>

\footnotetext{
${ }^{7}$ NFTP Non Forest Timber Products, es refereix als productes naturals extrets del bosc excepte la fusta. A MKP a part de nombrosos productes naturals també es recullen nombroses espècies de plantes medicinals, el focus d'aquest article. La comercialització de les plantes medicinals està restringida a certes companyies comercials i a certes ONGDs.

${ }^{8}$ Un Taluk és l'agrupació de municipis que fa el govern indi per sota el nivell de Districte.
} 


\section{perifèria}

Número 7, diciembre 2007

www. periferia. name

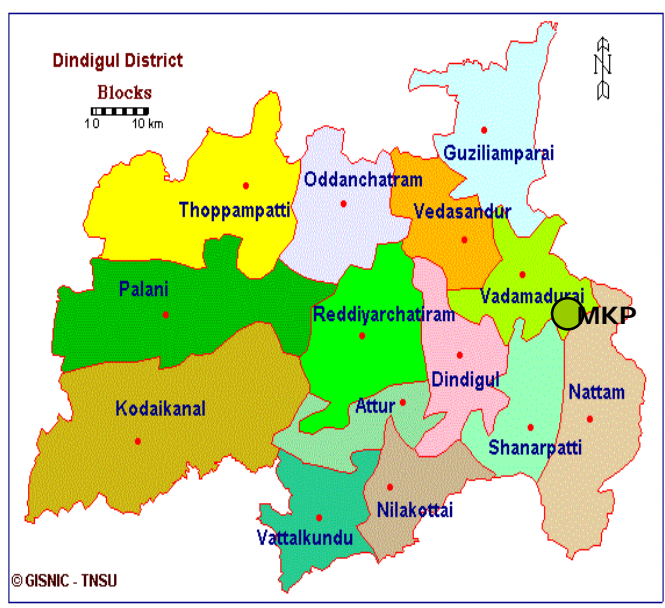

II-Iustració 2. Mapa del Districte de Dindigul Font: gisd.tn.nic.in/tnmaps/taluk.asp?dcode='DGL'

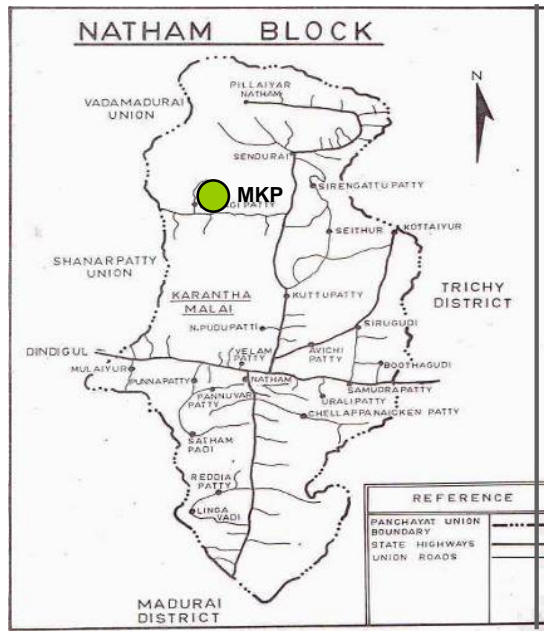

I I-Iustració 3. Mapa del Taluk de Natham Font: Annual Report CCD 2005-2006 (2006: 15)

MKP es situa just als peus de les Muntanyes de Karandamalai, sota el Panchayat ${ }^{9}$ de Kudagipatti, el qual engloba a 16 municipis del voltant de Karandamalai i altres pobles de la plana de Natham.

En els inicis el Manthaikulam- gent al voltant d'una bassa natural d'aiguarepresentava una important font d'aigua al centre del poble, usada per beure humans i animals, per rentar la roba, per higiene, per regar els camps de cultiu... etc. El Kulam o bassa d'aigua des dels inicis representava i fins avui en dia representa, el centre de trobada de la comunitat. El sufix Patti - significa poble en aquesta regió de Tamil Nadu. Així és com es composa l'etimologia del pobleManthakulathupatti.

El Departament d'Estadística de Tamil Nadu, en el Panchayat de Kudagipatti, s'hi registren unes 4.724 persones i unes 1.050 unitats familiars. Així doncs, MKP és un poblet petit dins el Panchayat de Kudagipatti, amb unes 70 unitats familiars i gairebé 400 habitants.

\footnotetext{
${ }^{9}$ El Panchayat és l'organisme governamental indi de base, agrupen a diferents municipis sota la seva gestió i la seva elecció es realitza cada quatre anys.
} 


\section{perifèria}

Número 7, diciembre 2007

www. periferia. name

Dos punts importants en la història de MKP marquen en bona part el seu estat actual. En primer lloc l'entrada dels primers comerciants de Dindigul per la tala i comercialització d'arbres va provocar una greu pèrdua de biodiversitat durant els anys 40, no aturada fins al decret de boscos reservats l'any 1977. En segon lloc, l'entrada dels comerciants de Dindigul per a la compra de plantes medicinals a principis dels anys 90 va orientar la dependència dels habitants de MKP cap a aquesta activitat econòmica, que fins aquell moment només es duia a terme per l'autoconsum. Així doncs, al nostre entendre l'entrada del mercat va intensificar la dependència econòmica dels seus habitants i va incentivar la sobreexplotació del medi.

Les activitats de subsistència a MKP van molt lligades amb els recursos naturals, es necessita l'aigua de la pluja per a cultivar i per a fer créixer els productes naturals que puguin oferir els boscos de Karandamalai.

En base a les dades publicades en l'estudi de Van Loon, Narasimhan, et al (2005), i al meu propi treball de camp, l'economia a les muntanyes de Karandamalai està centrada en l'agricultura de secà, en la cura del bestiar, en la recollida d'arbres fruiters i sobretot el la recol.lecció de productes del bosc (NFTP), entre ells les plantes medicinals. També hi ha persones que migren temporalment en busca de treball per guanyar uns ingressos addicionals. Concretament les principals activitats de sustent a MKP són:

a) Recollida i comercialització de plantes medicinals i altres NFTP.

b) Cultiu i recollida de Tamarinde, Mango i altres fruits del bosc.

c) Cultiu de secà per a l'autoconsum.

d) Altres ocupacions com: sastres, carters, treballadors en la restauració.

e) Migració laboral temporal o estable.

Per situar aquestes activitats en relació al sustent de les famílies de MKP, veiem interessant descriure com es distribueixen al llarg del calendari estacional com es mostra a continuació. 


\section{perifèria}

Número 7, diciembre 2007

www. periferia. name

\begin{tabular}{|c|c|c|c|c|c|c|c|c|c|c|c|c|}
\hline Activitats de subsistència & Gener & Febrer & Narç & Abril & Maig & Juny & Juliol & Agost & Setembre & Octubre & Norembre & Desembre \\
\hline \multicolumn{13}{|l|}{ Treballs agricoles } \\
\hline Preparació de la Terra & & & & $x$ & $x$ & & & & & & & \\
\hline Piantació & & & & & I & $\mathrm{I}$ & & & & & & \\
\hline Manteniment de la collita & & & & & & & $\mathrm{I}$ & $x$ & 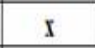 & $x$ & & \\
\hline Recollecció & $x$ & & & & & & & & & $x$ & $x$ & $x$ \\
\hline \multicolumn{13}{|l|}{ Recollecció de plantes medicinals } \\
\hline Alta disponibilitat de plantes medicinals & & & & & & & $x$ & $x$ & $x$ & $x$ & $x$ & $x$ \\
\hline Baixa disponibilitat de plantes medicinals & $y$ & I & I & $\mathrm{s}$ & $\mathrm{I}$ & $x$ & & & & & & \\
\hline \multicolumn{13}{|l|}{ Cultiu de Tamarinde } \\
\hline \multicolumn{13}{|l|}{ Manteniment dels arbres } \\
\hline Recollecció & & & 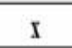 & $x$ & & & & & & & & \\
\hline \multicolumn{13}{|l|}{ Cultiu de Mango } \\
\hline Manteniment dels arbres (poda i fertilitzants) & & & I & $x$ & $\mathrm{~s}$ & & & & & & & \\
\hline Recollecció & & & & & & $x$ & $x$ & $x$ & & & & \\
\hline \multicolumn{13}{|l|}{ Recollecció de Mel } \\
\hline \multicolumn{13}{|l|}{ Migració Laboral } \\
\hline Treballs agricoles ide recollecció de fruita (Mango) & & & & & & 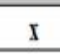 & I & I & I & I & & \\
\hline Recollecció de plantes medicinals & $x$ & $x$ & $x$ & & & & & & & & & $x$ \\
\hline
\end{tabular}

I I-Iustració 4. Estacionalitat de les activitats de subsistència a MKP Font: Elaboració pròpia al llarg del treball de Camp

En aquest quadre s'observa com la única activitat que es sustenta al llarg de tot l'any és la recollida i comercialització de plantes medicinals. En segon Iloc ubiquem la recol.lecció de tamarinde (abril i Maig) i mango (Març a Maig manteniment dels arbres i de Maig a Agost la recol.lecció). Finalment el cultiu de secà de diferents cereals es realitza durant l'estació de pluges que va de Juny a Desembre.

La major part dels habitants de MKP es poden considerar pluritreballadors (coolies en anglès), ja que alternen diferents activitats per aconseguir els mínims ingressos necessaris per sobreviure. Els treballs agrícoles i de recol-lecció que fan molts jornalers, estan valorats a 80 Rupies al dia per als homes $\left(1,41 €^{10}\right)$ i a 30 Rupies per a les dones $(0,538 €)$. Uns salaris bastant reduïts per jornades de 10 hores, i en molts casos fora de casa. També es fa patent una clara diferència salarial respecte al gènere. La inestabilitat dels ingressos genera en algunes famílies la necessitat de migrar per obtenir uns ingressos mínims.

\footnotetext{
${ }^{10}$ Tasa de canvi a Maig del 2007: un Euro equival a 0,56 Rupies.
} 


\section{perifèria}

Número 7, diciembre 2007

www. periferia. name

Del recull d'entrevistes realitzades per aquest treball ( $N=103$ o $47 \%$ dels adults a MKP) podem extreure els ingressos mitjos aproximats per unitat familiar.

\begin{tabular}{|c|c|c|c|c|c|c|}
\hline $\begin{array}{c}\text { Ingrés } \\
\text { Familiar } \\
\text { Mensual } \\
\text { (Rupies) }\end{array}$ & Total & $\%$ & Homes & $\%$ & Dones & $\%$ \\
\hline $1.0-500$ & 26 & $25,24 \%$ & 11 & $23,91 \%$ & 15 & $26,32 \%$ \\
\hline $2.500-1.000$ & 62 & $60,19 \%$ & 29 & $63,04 \%$ & 33 & $57,89 \%$ \\
\hline 3. $1.000-1.500$ & 8 & $7,77 \%$ & 3 & $6,52 \%$ & 5 & $8,77 \%$ \\
\hline 4. $1.500-2.000$ & 3 & $2,91 \%$ & 1 & $2,17 \%$ & 2 & $3,51 \%$ \\
\hline $5.2 .000-2.500$ & $\mathbf{0}$ & $0,00 \%$ & 0 & $0,00 \%$ & 0 & $0,00 \%$ \\
\hline $6.2 .500-3.000$ & 2 & $1,94 \%$ & 1 & $2,17 \%$ & 1 & $1,75 \%$ \\
\hline $7.3 .000-3.500$ & 0 & $0,00 \%$ & 0 & $0,00 \%$ & 0 & $0,00 \%$ \\
\hline $8.3 .500-4.000$ & 2 & $1,94 \%$ & 1 & $2,17 \%$ & 1 & $1,75 \%$ \\
\hline Total & 103 & $100 \%$ & 46 & $100 \%$ & 57 & $100 \%$ \\
\hline & & & $44,66 \%$ & & $55,34 \%$ & \\
\hline
\end{tabular}

II-lustració 5. Ingressos monetaris mensuals de les unitats familiars a MKP 2007.

Font: Elaboració pròpia a partir de la informació extreta de l'Anàlisi de Xarxes Socials

Veiem que un $85 \%$ de les persones entrevistades ingressen mensualment per unitat familiar un màxim de 1.000 Rupies, uns 17,86€. Així doncs, diàriament això representa uns $0,56 €$ per unitat familiar, cosa que situa a aquestes famílies per sota del llindar de la pobresa, establert a un euro diari per persona ${ }^{11}$.

És important veure que el sustent de les famílies de MKP no només depèn dels ingressos monetaris, també hem de tenir en compte les activitats destinades a l'autoconsum, com el cultiu d'aliments en l'època de pluges, la cura de bestiar durant tot l'any i la fabricació artesanal de productes i estris.

En un estudi fet per les ONGDs ATREE-CCD (2006:16) es compara el volum d'ingressos i despeses, tant monetaris com no monetaris, de quatre municipis de Karandamalai, dos situats al cim de les muntanyes i dos als seus peus. En aquest estudi es posa de relleu que MKP és el municipi amb menys poder adquisitiu a nivell global. Veiem que MKP depèn principalment dels ingressos que ofereix el bosc, concretament de la recollida i venda de plantes medicinals (tant a nivell monetari

${ }^{11}$ En els Objectius del Mil-lenni (Informe 2007) del Banc Mundial, es descriu que el llindar de la pobresa s'estableix en 1 euro per persona al dia. 


\section{perifèria}

Número 7, diciembre 2007

www. periferia. name

com no monetari). En canvi els ingressos provinents de l'agricultura són bastant reduïts. Aquest fet s'explica perquè MKP depèn del cultiu de secà, on només s'utilitza l'aigua de la pluja, mentre que a la resta de pobles les facilitats d'aigua són majors. La cura del bestiar a MKP tampoc representa grans ingressos i es destinada majoritàriament a l'autoconsum.

També en l'estudi CCD-ATREE (2006: 20), es descriuen les principals despeses de les unitats familiars a Karandamalai. El menjar és el principal cost de les famílies amb un $66 \%$, seguit de costos culturals i socials com serien la celebració de cerimònies, festivals religiosos, etc. amb un $24 \%$ de la despesa. En tercer terme amb un $7 \%$ segueixen les despeses en salut i finalment el $3 \%$ el formen les despeses en educació. Aquest estudi mostra com els habitants a Karandamalai i entre ells els de MKP, tenen un consum molt bàsic amb una significativa despesa religiosa.

\section{Aproximacions a la sustentabilitat en la recollida de plantes medicinals a MKP}

Un cop descrites les principals característiques de MKP, ens aproximem a l'anàlisi de la sustentabilitat dels dos sistemes de comercialització de plantes medicinals al poble. Qui proporciona aquests ingressos i quins efectes té per a MKP i per els boscos de karandamalai, són les preguntes que intentem resoldre a continuació.

\section{Sistema de mercat}

Els primers comerciants de plantes medicinals van arribar a MKP fa més de 15 anys, després d'obtenir el permís comercial per part del Departament Forestal de Tamil Nadu. Els comerciants provenen principalment de Dindigul, la capital del Districte, encara que també hi ha algun comerciant de Natham. Hem pogut definir dos patrons comercials que estableixen els habitants de MKP amb els comerciants de Dindigul.

En primer lloc trobem a diverses famílies de recol-lectors de plantes medicinals que recullen i processen les plantes a nivell individual o familiar i les venen als comerciants de Dindigul. Les espècies recol-lectades les marquen els mateixos comerciants que posteriorment arriben a MKP i realitzen el tracte. El preu pagat per 


\section{perifèria}

Número 7, diciembre 2007

www. periferia. name

les plantes medicinals és inferior al preu que es compra al mercat de Dindigul. En aquest cas els recol-lectors han d'assumir els costos de transport fins al mercat.

El segon patró comercial definit a MKP l'estableixen diferents parelles de recol-lectors que informalment col-laboren amb altres famílies del poble per la recol. lecció i venda conjunta als comerciants de Dindigul. Aquest grup informal de recol-lectors d'unes vuit parelles, tenen unes condicions comercials més favorables que la resta d'habitants que comercialitzen a nivell individual, ja que el transport queda assumit pels mateixos comerciants. Els preus segueixen sent molt inestables, perdent valor a l'època de pluges (Agost a Novembre), on hi ha més disponibilitat de plantes medicinals als boscos de karandamalai.

\section{Sistema cooperatiu a través de la ONGD CCD}

El grup de recol-lectores “Murugan Moligai Sangam” es va constituir l'any 2001 gràcies a la promoció que en va fer el coordinador de la ONGD CCD a l'àrea de Natham. A través de l'alcalde algunes famílies que en aquell moment estaven comercialitzant les plantes medicinals a través d'intermediaris comercials de Dindigul, van decidir apuntar-s'hi.

Van ser les dones, segons ens expliquen diversos informants, les que van tenir l'empenta de formar el grup. Més endavant quan les coses començaven a anar bé, molts homes també es van interessar per comercialitzar les plantes medicinals a través del grup de recol-lectores del CCD, encara que sense formar-ne part. El grup resultant format per 32 dones, té els següents objectius:

- Donar ocupació als habitants de MKP a través de la recollida de plantes medicinals, tot oferint un canal de comercialització alternatiu al mercat.

- Fomentar pràctiques de recol.lecció i processament sostenibles.

- Fomentar la unió regional dels grups de recol-lectores de la ONGD CCD, per introduir millores i intercanviar experiències i negociar les condicions comercials de forma conjunta.

- Fomentar l'estalvi i els microcrèdits entre els membres del grup per a situacions d'emergència (problemes de salut, problemes educatius, per cerimònies culturals i religioses, etc.). Amb una aportació mensual de 50R. 


\section{perifèria}

Número 7, diciembre 2007

www. periferia.name

Recordem que donada la baixa capacitat d'estalvi de les famílies de MKP, aquesta activitat dóna un marge de seguretat vital per als seus habitants i complementa els objectius comercials del grup.

L'evolució del nombre de membres ha estat constant al llarg dels sis anys de funcionament. Tot i que alguns membres han sortit del grup per desinterès o per conflictes interns, altres han entrat a formar-ne part.

La relació del grup amb la ONGD CCD és bàsicament comercial i de suport logístic. Encara que també es donen capacitacions i es fan reunions conjuntes per al funcionament dels grups per fomentar pràctiques sostenibles de recollida i processament i també per fomentar la cultura local ${ }^{12}$. Un cop a l'any els membres del grup es reuneixen al Centre Sevaiyur, a $50 \mathrm{~km}$ de Madurai, amb més de 300 grups de recol-lectores i amb l'equip tècnic del CCD (més de 140 treballadors), on es discuteixen i s'intenten resoldre els problemes dels grups, també s'avaluen resultats i es dissenya el pla d'acció per l'any següent. També a nivell de la companyia cooperativa $\mathrm{GMCL}^{13}$ hi ha reunions periòdiques amb els presidents dels diferents grups, en aquest cas de l'àrea de Natham, per tractar les condicions comercials i logístiques entre els grups de recol·lectors i la cooperativa.

El Centre de Sevayiur, construït pel CCD l'any 1998 com a centre rural de treball prop de Madurai, es dedica a la preservació de la cultura local a través de les plantes medicinals. S'han realitzat nombrosos estudis amb investigadors locals identificant-se més de 340 espècies de plantes medicinals així com els remeis naturals i les pràctiques de salut associades. També s'ha construït un centre de conservació de llavors i un centre de cultiu per a la preservació de les espècies. L'eix bàsic és la col·laboració de les comunitats locals en la captació de tot aquest

\footnotetext{
12 El Projecte "Kitchen Herbal Garden", també fomentat per al CCD amb l'objectiu de difondre la cultura local, es basa en la creació d'un jardí casolà amb plantes medicinals i aliments per l'autoconsum. A més el CCD intercanvia coneixements respecte els remeis associats i les seves aplicacions. Cal dir però, que a MKP al llarg de treball de camp no he pogut observar cap projecte d'aquestes característiques, si però en altres pobles on opera el CCD.

${ }^{13}$ Grama Mooligai Company Limited (GMCL) companyia cooperativa per la comercialització de plantes medicinals i altres NFTP fomentada pel CCD. Aquesta companyia es va registrar l'any 2001 i actualment conté a més de 300 grups de recol-lectors que comercialitzen conjuntament les plantes medicinals amb diferents clients del mercat nacional de productes naturals indi.
} 


\section{perifèria}

Número 7, diciembre 2007

www. periferia. name

coneixement local, especialment dels Naattu Vaidhyar, especialistes tradicionals dels sistema natural de medicina Siddha. Finalment també es realitzen tasques de difusió i educatives de tot el coneixement i pràctiques rurals entre les comunitats.

Així doncs, tot i que el grup de recol-lectores de MKP és una petita peça dins el teixit de la companyia cooperativa GMCL, en base a l'Ecologia Política no podem perdre de vista l'impacte regional i fins hi tot estatal d'aquesta empresa cooperativa liderada per grups de recol·lectors rurals.

\section{Aproximacions a la sustentabilitat del sistema de mercat i cooperatiu de recollida i comercialització de plantes medicinals a MKP}

Dimensió Tecno-Econòmica

A l'hora de valorar les primeres aproximacions a la sustentabilitat econòmica, és important tenir present que tot i la dualització que presentem en la comercialització de plantes medicinals via mercat o via cooperativa, també trobem relacions comercials mixtes a MKP, amb recol-lectors que comercialitzen tant a través del grup cooperatiu del CCD, com a través del mercat. Hi ha certes espècies de plantes medicinals que GMCL no comercialitza i que per tant, només es venen a través del mercat.

Segons hem pogut veure al llarg del treball de camp, la recollida i processament de les plantes medicinals a MKP és a nivell individual o familiar. Per tant, Només a l'estació seca, quan hi ha una menor disponibilitat de plantes medicinals i els recol-lectors han d'anar a fora de les muntanyes de Karandamalai, la recol.lecció es fa de manera conjunta entre els membres del grup cooperatiu, però la divisió del volum recollit, segueix sent per aportació individual. Aquesta activitat té uns costos de transport associats que han d'assumir els recol-lectors tan en el sistema de mercat com via GMCL. Els patrons extractius del sistema de mercat i del sistema cooperatiu no s'allunyen massa.

Per la recollida de plantes medicinals, segons els mateixos recol-lectors ens expliquen, no s'utilitzen massa eines: Chuck (ganivet), Torreti (pal amb un ganxo al capdamunt) i Karakatú (cistell per portar les plantes). Aquests estris els té cada família des de fa molts anys i no suposen un cost addicional per als recol-lectors. 


\section{perifèria}

Número 7, diciembre 2007

www. periferia.name

Un cop recollides les plantes es processen al poble, habitualment davant les cases de cada família. En el processament de les plantes s'utilitzen tècniques molt simples, com separar fulles de branques, deixar assecar al sol durant uns dos o tres dies, treure les impureses, etc. Tot i que el procés és simple, és important per la qualitat final obtinguda i per tant el preu final rebut. El processament també es fa a nivell individual o familiar en ambdós sistemes.

A nivell comercial trobem més diferències entre el sistema de mercat i el sistema cooperatiu. La comercialització amb el CCD es fa a través de l'empresa cooperativa GMCL, mentre que les famílies que comercialitzen amb el mercat, tenen unes dures condicions comercials tractant directament amb els intermediaris comercials.

GMCL té un patró comercial molt novedós i per la qual cosa va estar replicat a altres parts de la India l'any $2005^{14}$. La cúpula de la GMCL, formada per diferents representants dels grups de recol-lectors, pacta les condicions comercials amb els seus clients a principis d'any. En funció de la quantitat total demandada es fixa un preu estable per tot l'any, que es retribueix als recol-lectors en cada entrega.

El preus que pacta el GMCL es distribueixen de la següent manera: un $70 \%$ del preu pactat és per als recol-lectors en funció de la quantitat aportada; un $10 \%$ és en concepte de despeses administratives per mantenir l'estructura de GMCL; un altre $10 \%$ és per les tasques de foment, capacitació i logística assumida per la ONGD CCD; finalment el 10\% restant es destina a "beneficis" a repartir a final d'any entre els diferents grups de recol-lectors.

La relació comercial establerta entre $G M C L, C C D$, i els grups de recol-lectors i cultivadors de plantes medicinals ${ }^{15}$ es pot veure clarament en la següent il.lustració:

\footnotetext{
${ }^{14}$ Banc Mundial va donar suport a aquesta iniciativa a l'Estat de Orissa.

${ }^{15}$ A MKP no existeix de moment cap grup de cultiu de plantes medicinals degut a l'escassetat d'aigua per regar.
} 


\section{perifèria}

Número 7, diciembre 2007

www. periferia.name

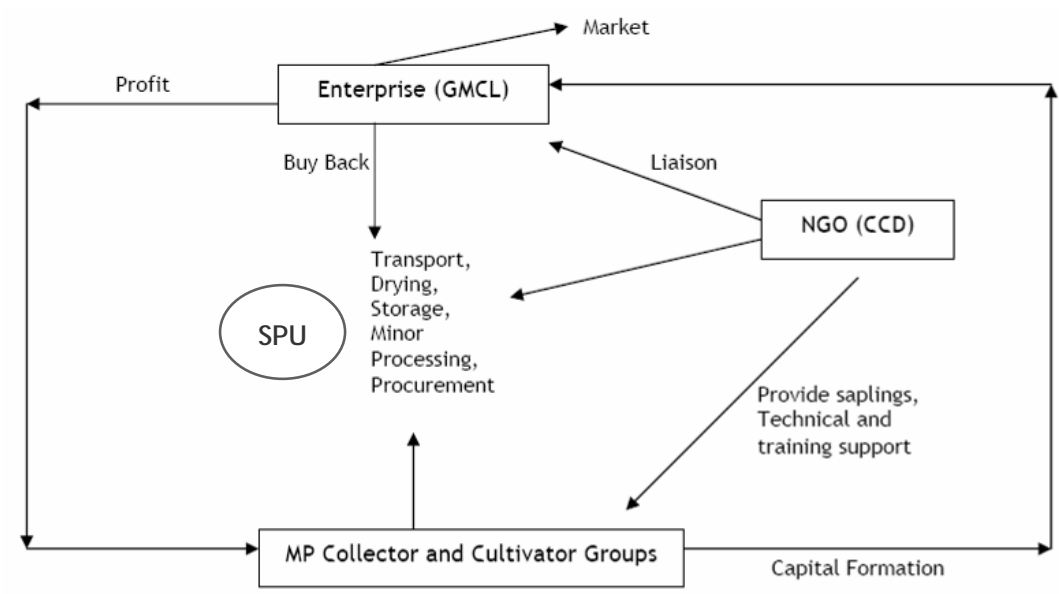

I I-Iustració 6. Estructura comercial de GMCL

Font: CCD Medicinal Plants, From Local Resource To Local-Community Enterprise (2005:14)

L'estructura de preus de GMCL, segons es llegeix en diferents publicacions del CCD, a part de mantenir uns preus més estables que el mercat, conté una part estratègica important, ja que els seus membres participen en la presa de decisions interactuant també amb el mercat. Veiem una clara aposta de mercat en l'estratègia comercial de GMCL.

Les SPU (Semi Processing Units) que apareixen el la il-lustració 6, representen els centres d'emmagatzematge de plantes medicinals descentralitzats en les diferents àrees d'acció ${ }^{16}$. Aquests centres emmagatzemen les plantes medicinals dels diferents recol-lectors locals i les distribueixen a GMCL perquè les vengui als clients finals. A MKP, un cop les plantes arriben al centre de Manakkattur es pesen i es valora la seva qualitat, determinant el preu final. Al cap d'una setmana els recol·lectors reben el pagament en funció de la quantitat i qualitat recollida.

Un altre punt important són les condicions logístiques per al transport de les plantes, gestionades per CCD, i no assumides per als grups de recol-lectors, com també s'observa en la il-lustració. El procés comercial a través de GMCL assumeix el cost dels intermediaris comercials que realitzen tasques logístiques i de

\footnotetext{
${ }^{16}$ La cooperativa GMCL té 6 Centres d'emmagatzematge o (Semi Processing Units -SPU), un d'ells és el centre de Manakkattur, dins de l'àrea de Natham, on MKP representa en dades del 2005 , el $33 \%$ del volum emmagatzemat.
} 


\section{perifèria}

Número 7, diciembre 2007

www. periferia. name

pagament. A MKP l'intermediari comercial és l'alcalde del poble, el qual rep un petit sou des del CCD.

Les condicions que ofereix el mercat de Dindigul respecte a preu i a quantitat demandada són molt inestables, baixant els preus a límits d'explotació durant l'època de pluges, l'època que hi ha més disponibilitat de plantes a Karandamalai. Els costos de transport s'assumeixen per part dels recol-lectors i els criteris de determinació de la qualitat de les plantes, i per tant el preu final, en molts casos són abusius per part dels comerciants.

En el quadre següent es comparen els sistemes de compra entre els comerciants de Dindigul i a través de la cooperativa GMCL fomentada per la ONGD CCD:

Principals espècies de Plantes Medicinals Comercialitzades a MKP 2006

\begin{tabular}{|c|c|c|c|c|c|c|c|c|c|c|c|c|}
\hline \multirow{3}{*}{$\begin{array}{l}\text { Nom en } \\
\text { Tamil }\end{array}$} & \multirow{3}{*}{ Nom en llatí } & \multirow{3}{*}{ Usos de les plantes } & \multirow{3}{*}{$\begin{array}{c}\text { Part de la } \\
\text { planta } \\
\text { comercialit } \\
\text { zada }\end{array}$} & \multirow{2}{*}{\multicolumn{2}{|c|}{$\begin{array}{c}\text { Volum Recollit }(\mathrm{Kg} / J \text { Jornada } \\
\text { de treball) }\end{array}$}} & \multicolumn{3}{|c|}{ GMCL-CCD } & \multicolumn{4}{|c|}{ Comerciants de Dindigul } \\
\hline & & & & & & \multirow{2}{*}{$\begin{array}{c}\text { PREU } \\
\text { (Rupies) } \\
\text { Tot l'any }\end{array}$} & \multicolumn{2}{|c|}{$\begin{array}{c}\text { Ingressos per } \\
\text { Jornada }\end{array}$} & \multicolumn{2}{|c|}{ PREU (Rupies) } & \multicolumn{2}{|c|}{$\begin{array}{l}\text { Ingressos per } \\
\text { Jornada }\end{array}$} \\
\hline & & & & $\begin{array}{l}\text { Estació } \\
\text { seca }\end{array}$ & $\begin{array}{c}\text { Estació de } \\
\text { pluges }\end{array}$ & & $\begin{array}{c}\text { Estació } \\
\text { seca }\end{array}$ & $\begin{array}{c}\text { Estació } \\
\text { de pluges }\end{array}$ & $\begin{array}{c}\text { Estació } \\
\text { seca }\end{array}$ & $\begin{array}{c}\text { Estació } \\
\text { de pluges }\end{array}$ & $\begin{array}{c}\text { Estació } \\
\text { seca }\end{array}$ & $\begin{array}{l}\text { Estació } \\
\text { de pluges }\end{array}$ \\
\hline Usilai & Albizia amara & Complements nutricionals & fulles & $5-10 \mathrm{~kg}$ & $20-30 \mathrm{~kg}$ & $2-3 R$ & 15 & 90 & $3-4 R$ & $2 \mathrm{R}$ & 17.5 & 60 \\
\hline $\begin{array}{l}\text { Neem Leaf } \\
\text { (vepala) }\end{array}$ & Azadirachta indica & $\begin{array}{l}\text { Multiples usos terapètuics i } \\
\text { desinfectants. Usada per problemes } \\
\text { de pell }\end{array}$ & fulles & $5-10 \mathrm{~kg}$ & $10-20 \mathrm{~kg}$ & $4-5 R$ & 25 & 100 & $7 \mathrm{R}$ & $5 \mathrm{R}$ & 35 & 100 \\
\hline Saranathi & Boerhavia diffusa & $\begin{array}{l}\text { Múltiples usos terapèutics, una de } \\
\text { les plantes més valorades dins la } \\
\text { medicina Siddha i Ayurvèdica }\end{array}$ & $\begin{array}{l}\text { tota la } \\
\text { planta }\end{array}$ & $5 \mathrm{~kg}$ & $10-20 \mathrm{~kg}$ & $5-6 \mathrm{R}$ & 30 & 120 & $6 \mathrm{R}$ & $2 \mathrm{R}$ & 30 & 40 \\
\hline Perendai & Cissus quadrangularis & $\begin{array}{c}\text { Traumatismes i Ostereoporosis, } \\
\text { complement nutricional, analgèsic, } \\
\text { etc }\end{array}$ & $\begin{array}{l}\text { tota la } \\
\text { planta }\end{array}$ & $1-3 \mathrm{~kg}$ & $10 \mathrm{~kg}$ & $20-25 R$ & 20 & 250 & $26 \mathrm{R}$ & $10-18 \mathrm{R}$ & 26 & 100 \\
\hline Mevanalli & Phyllanthus maderaspatensis & Analgèsic $\mathrm{i}$ complement nutricional & fulles & $1-3 \mathrm{~kg}$ & $10 \mathrm{~kg}$ & $5-6 \mathrm{R}$ & 18 & 60 & No inf. & No inf. & & \\
\hline Avaram & Cassia auriculata & Sabó & fulles & $6 \mathrm{~kg}$ & $10 \mathrm{~kg}$ & $5-7 \mathrm{R}$ & 42 & 70 & $8 \mathrm{R}$ & $4 \mathrm{R}$ & 48 & 40 \\
\hline $\begin{array}{l}\text { Mookana } \\
\text { Saranathi }\end{array}$ & Boerhavia erecta & $\begin{array}{l}\text { Múltiples usos terapèutics, una de } \\
\text { les plantes més valorades dins la } \\
\text { medicina Siddha i Ayurvèdica }\end{array}$ & arrel & $2 \mathrm{~kg}$ & $10 \mathrm{~kg}$ & $8-10 \mathrm{R}$ & 16 & 100 & $\begin{array}{l}\text { No es } \\
\text { ven }\end{array}$ & $\begin{array}{l}\text { No es } \\
\text { ven }\end{array}$ & & \\
\hline Peru Kurinja & Vattakakka volublis & Analgèsic & fulles & $1 / 2-2 \mathrm{~kg}$ & $3-5 \mathrm{~kg}$ & $22,5 \mathrm{R}$ & 22.5 & 112.5 & $27 \mathrm{R}$ & $15-20 \mathrm{R}$ & 27 & 100 \\
\hline Siru Kurinja & Gymnema sylvestre & $\begin{array}{l}\text { Analgèsic i per transtorns en el } \\
\text { sucre com la Diabetes }\end{array}$ & fulles & $1 / 2-2 \mathrm{~kg}$ & $3-5 \mathrm{~kg}$ & $22,5 \mathrm{R}$ & 22.5 & 112.5 & $27 \mathrm{R}$ & $15-20 \mathrm{R}$ & 27 & 100 \\
\hline & & & & & & & 211 & 1,015 & & & 211 & 540 \\
\hline
\end{tabular}

II-Iustració 7. Sistema de compra de plantes medicinals a MKP GMCL i Comerciants de Dindigul

Font: Elaboració pròpia amb dades del treball de camp

En primer lloc, es pot observar com la quantitat de plantes medicinals recollida varia a nivell estacional. Mentre a l'època seca es recullen de 1 a $10 \mathrm{~kg}$ depenent de 


\section{perifèria}

Número 7, diciembre 2007

www. periferia.name

l'espècie de planta medicinal, a l'època de pluges la quantitat per persona i dia incrementa fins a tres vegades més.

En segon $\|_{0 c}$, veiem com GMCL manté una mateixa estructura de preus $\tan a$ l'època seca com en l'època de pluges, cosa que implica un ingrés aproximat de la suma de totes les espècies de plantes medicinals de $211 \mathrm{R}$ en l'època seca i 1.015R en l'època de pluges. En canvi els comerciants de Dindigul tenen una estructura de preus molt desigual, disminuint el preu pagat a més de la meitat en l'època de pluges. Aquest fet com s'observa en la darrera línia de la taula, implica que en l'època seca es rebin $211 \mathrm{R}$ per persona i dia acumulant totes les espècies recollides, igual que en la comercialització via GMCL, però només 540R en l'època de pluges, gairebé un 50\% menys que GMCL. Veiem doncs una clara diferència entre el sistema de retribució del mercat i de l'empresa cooperativa GMCL.

Segons dades dels grups focals realitzats al llarg del treball de camp, els ingressos del grup de recol-lectores de GMCL van ser de unes 305.500R (5.390€) al 2000, amb un volum de $45.660 \mathrm{~kg}$, i de 201.563R (3.557€) al 2006, amb un volum de $30.135 \mathrm{Kg}$. Veiem doncs, un descens important en la xifra total generada entre el 2000 i el 2006. No disposem de dades més concretes de l'evolució dels ingressos de cada any, però podem indicar una tendència al decreixement dels ingressos del grup de recol-lectores del CCD. Aquest descens es pot explicar per la baixa disponibilitat d'algunes espècies a les muntanyes de Karandamalai, que limiten el volum de recol.lecció.

Respecte a la cadena de comercialització final tan en el mercat com via GMCL, els clients finals són les companyies farmacèutiques nacionals de productes naturals. Els principals compradors de GMCL són nacionals o locals, segons dades secundàries del centre d'emmagatzematge de Manakkattur.

Destaquem a l'empresa Himalayan Herbs amb un $40 \%$ del total de compres de les espècies Neem leaf (Azadirachta indica) i Saranathi (Boerhavia diffusa). En segon Iloc trobem a Natural Remedies amb un 20\% comprant les espècies Saranathi (Boerhavia diffusa), Usilai (Albizia amara), Keevanelli (Phyllanthus amarus) i Sirianangai (Andrographis paniculada) i a l'empresa Medi Herbs també amb un 20\%, comprant només Usilai (Albizia amara) i Avaram (Cassia auriculata). 


\section{perifèria}

Número 7, diciembre 2007

www. periferia. name

Finalment els comerciants de Dindigul representen un $20 \%$ de les compres en varies espècies de plantes medicinals. Veiem com la demanda del mercat final condiciona la recol.lecció de certes espècies, i pot afectar-ne la seva disponibilitat a Karandamalai.

Així doncs, econòmicament em sembla important comentar que GMCL dóna unes millors condicions que el mercat amb estabilitat de preus i accions logístiques, també hi ha un treball cooperatiu a nivell estratègic, ja que els grups participen en la presa de decisions. Tot i això, donada l'escassetat de pluges i la sobreexplotació de plantes medicinals ens preguntem si la recollida i comercialització és sustentable a nivell econòmic? La baixa disponibilitat de plantes medicinals a Karandamalai poden fer incrementar els costos de transport per anar a recollectar en altres boscos més llunyans. A més els preus estables però no molt elevats que ofereix GMCL, fan que el marge pels recol-lectors sigui baix, cosa que implica més volum de recol-lecció i per tant, es pot posar en dubte la sustentabilitat econòmica d'aquest grup a llarg termini.

Dimensió Social

La nostra tesi proposa que les esferes socials i culturals tenen una gran rellevància per explicar si realment els projectes de les ONGDs són o no sustentables, ja que aquestes dimensions no es tenen tan presents en la pràctica del desenvolupament sostenible. En la dimensió social tot i les múltiples indicadors que es poden avaluar, en aquest article analitzarem els processos de participació ciutadana a MKP, utilitzant la tècnica de xarxes socials ${ }^{17}$. També posarem èmfasi en la dependència econòmica i política d'aquests grups respecte al mercat (clients finals) i respecte als finançadors externs de la mateixa ONGD CCD, que en poden condicionar les línies estratègiques i fins hi tot la seva supervivència.

\footnotetext{
17 La xarxa definida està formada a partir de les dinàmiques de col-laboració en la recollida de plantes medicinals entre els diferents habitants de MKP. Es van fer entrevistes a 103 habitants amb una xarxa resultant de 213 persones, gairebé tots els adults de MKP, ja que segons dades de la llista de votants hi ha de 220 adults al poble.
} 


\section{perifèria}

Número 7, diciembre 2007

www.periferia.name

Per analitzar les dinàmiques relacionals o de col-laboració respecte a la recollida i comercialització de plantes medicinals en els dos sistemes de comercialització a MKP, mostrem les següents il·lustracions:

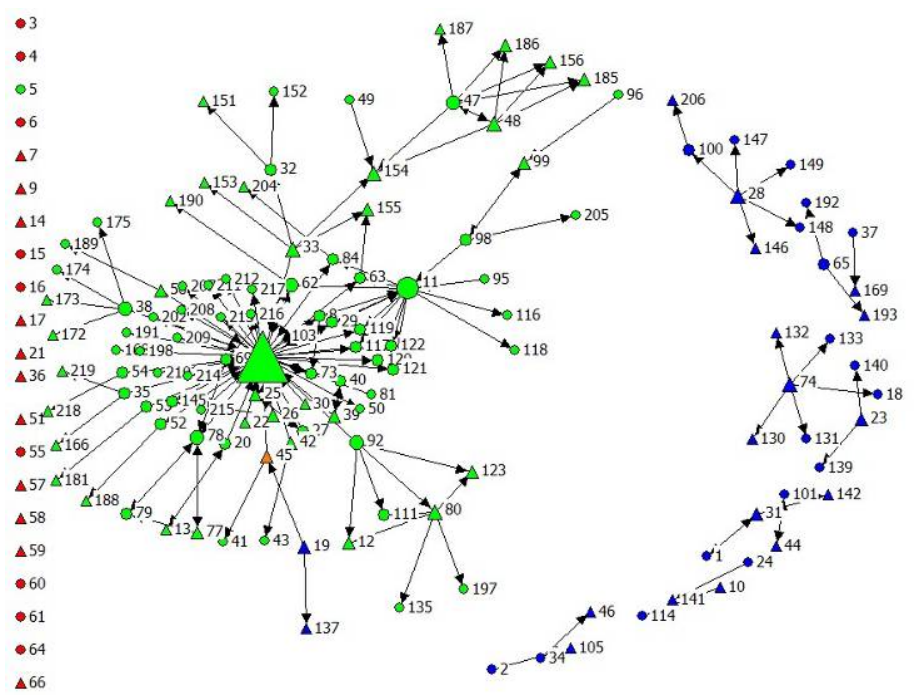

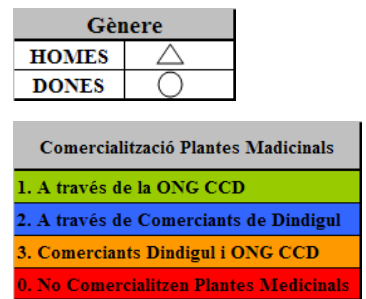

Tamany Nodes: Grau d'Intermediació

I I-Iustració 8. Xarxa de col·laboració en la comercialització de plantes medicinals a MKP Font: Elaboració pròpia amb dades del treball de camp

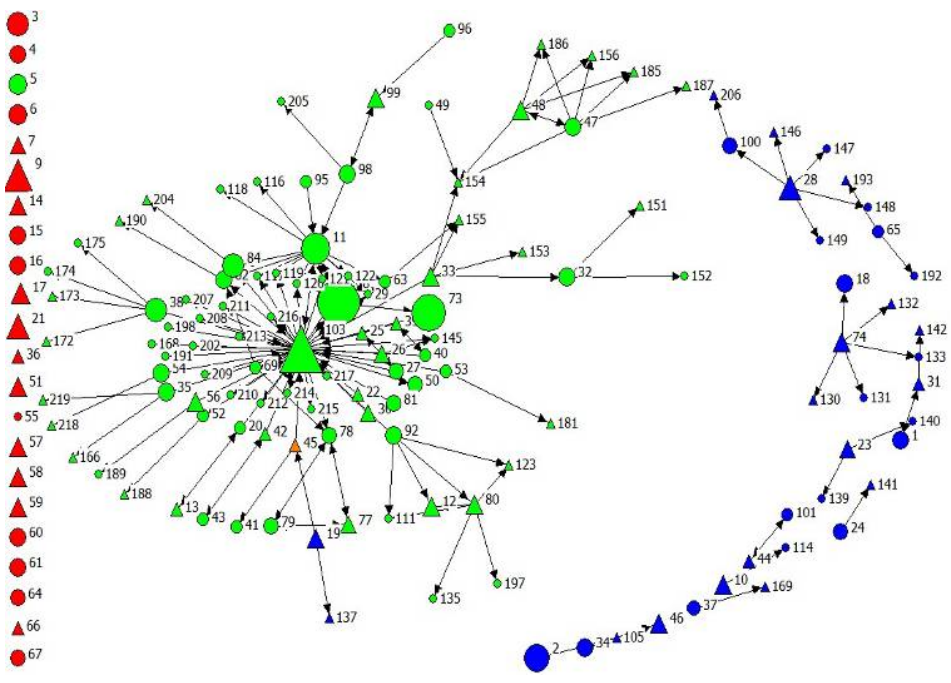

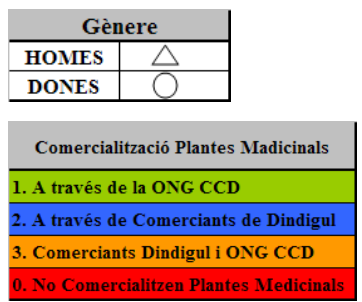

Tamany Nodes: Ingressos mensuals per Unitat familiar

II-Iustració 9. Xarxa de col·laboració en la comercialització de plantes medicinals a MKP Font: Elaboració pròpia amb dades del treball de camp

En la il-lustració 8 es mostra la xarxa de recol-lecció i comercialització de plantes medicinals a MKP. Podem apreciar un centre bastant cohesionat amb l'actor 103 al 


\section{perifèria}

Número 7, diciembre 2007

www. periferia. name

mig i amb el major grau d'intermediació ${ }^{18}$. Aquest actor és l'alcalde del poble i l'agent logístic del CCD a MKP. El segon actor amb major mediació és el node 11, la presidenta del grup de recol·lectores i filla de l'alcalde.

En la primera esfera del centre de la xarxa observem a totes les dones (forma rodona) membres del grup de recol-lectores, veiem com a través d'elles la resta de la família també accedeixen a la xarxa del CCD, de color verd. Observem també com altres famílies que no són membres del grup també venen les plantes medicinals a través de l'alcalde, reproduint el sistema de mercat encara que amb millors condicions. En termes generals veiem que el $75 \%$ dels recol-lectors de la xarxa de MKP (164 persones), comercialitzen a través del CCD (GMCL).

De color blau podem identificar el $25 \%$ restant (34 recol-lectors) que comercialitzen amb el mercat. A la part superior identifiquem un grup de recol-lectors informals que comercialitzen conjuntament $\mathrm{amb}$ el mercat $\mathrm{i}$ a sota veiem a la resta de famílies que venen les plantes als comerciants de Dindigul de forma individual.

Identifiquem també a 21 actors que no participen en la comercialització de plantes medicinals, la major part dels quals treballen fora de MKP.

Si comparem aquesta informació amb la il/lustració 9, on es mostra la mateixa xarxa però en aquest cas el tamany dels nodes representen els ingressos mensuals de les unitats familiars, veiem que el centre de la xarxa del CCD (color verd), està formada per actors amb un volum d'ingressos mensuals considerable. A la perifèria i comercialitzant amb el mercat trobem un grup de famílies amb uns ingressos mitjos. Aquest anàlisi ens pot ajudar a sustentar la tesi de Breton (2001), on s'explica com les classes altes i mitges de les comunitats rurals, són les intermediàries i principals beneficiàries de l'ajuda de les ONGD.

El grup de recol-lectores de GMCL té una alta participació al poble, tot i que no podem afirmar que aquesta sigui "democràtica", ja que bona part de la gent implicada en la xarxa de comercialització no forma part del grup, i per tant, no té accés en les decisions ni a les capacitacions de pràctiques de recol.lecció

18 El Grau d'Intermediació és un bon indicador del nivell de mediació que tenen els actors a nivell individual dins la xarxa, o sigui, les relacions que els uneixen amb altres actors. 


\section{perifèria}

Número 7, diciembre 2007

www. periferia.name

sostenibles que fomenta la ONGD CCD. La relació d'aquestes famílies de recol-lectors que no formen part de GMCL és una relació més clientelar que cooperativa.

Finalment només comentar breument en base a l'ecologia política, que també s'ha realitzat anàlisis sobre la dependència política i econòmica que tenen els grups de recol-lectors fomentats per la ONGD CCD. La mateixa ONGD CCD depèn de donants externs ${ }^{19}$, esdevenint una Organització de Segon Grau, cosa que ens pot posar en dubte la independència dels projectes i la seva supervivència a llarg termini. La dependència econòmica del mercat que conté l'estratègia comercial de GMCL també pot provocar limitacions a la sustentabilitat dels grups cooperatius, ja que si els les empreses nacionals de productes naturals baixen els preus de compra, GMCL no pot garantir-ne tampoc la seva estabilitat. Veiem doncs com els grups de recol-lectors depenen de l'estructura internacional de cooperació i també degut a la seva orientació estratègica, del mercat.

Dimensió Cultural

La definició de sustentabilitat que proposo implica que les activitats han d'incorporar el coneixement local i les seves pràctiques. En la literatura trobem a nombrosos projectes de ONGDs que han fracassat precisament per no tenir presents de forma acurada els processos culturals en relació amb el medi- Bonfill Batalla (1982), Cardoso de Oliveira (1992), i Stavenhagen (2001), entre altres.

Diferents investigadors han documentat la importància del coneixement ecològic tradicional i els seus efectes directes en societats sense accés a tècniques modernes d'agricultura o medicina (Johns 1997; Reyes-García et al. 2005a; Etkin 2000; Bentley i Rodríguez 2001; Kuhnlein i Turner 1991). Aquest fet presenta una pregunta clau: si el coneixement ecològic tradicional proporciona tants beneficis privats, per què hauria de desaparèixer? Els investigadors han assenyalat dues causes fonamentals per explicar la pèrdua de coneixement ecològic tradicional:

\footnotetext{
19 L'aparell del desenvolupament entre ells el Banc Mundial i ONGDs d'abast internacional com Ford Foundation i Oxfam són els principals finançadors del CCD, cosa que pot condicionar la tipologia dels projectes i en la seva permanència a llarg termini. Ens qüestionem si els donants desapareixen que passarà amb la mateixa ONGD CCD i amb la cooperativa GMCL?
} 


\section{perifèria}

Número 7, diciembre 2007

www. periferia.name

l'escolarització (Sternberg et al. 2001) i la integració al sistema de mercat (Benz et al. 2000; Locay 1989).

En el cas que ens ocupa veiem com el mercat està tenint certs impactes en el coneixement local a MKP, no només per la pèrdua del sistema local de salut (Siddha), sinó que també està introduint coneixements nous enfocats a l'intercanvi comercial.

En 50 anys $^{20}$ hi ha hagut importants canvis a MKP. El principal canvi, junt amb la reducció progressiva de les pluges, és el pas d'un sistema basat principalment en l'autoconsum, a un sistema de mercat. Aquest canvi no només afecta a nivell d'activitats de subsistència, sinó que també afecta al sistema de salut i per tant al coneixement ecològic local.

L'entrada durant els anys 90 dels primers comerciants de plantes medicinals va donar valor econòmic a una sèrie d'espècies de plantes medicinals, que fins al moment, només tenien un valor cultural i de salut per als habitants de MKP. Aquest canvi en la percepció de les plantes han interferit en gran mesura en la sobreexplotació del medi i amb la pèrdua de valor cultural.

Diversos autors, com Saravanan (2006), han documentat a Karandamalai l'extens coneixement ecològic local sobre les plantes medicinals i els seus usos associats: nombrosos remeis, recipients tradicionals i especialistes remeiers han estat estudiats. Actualment però, I'ús dels sistemes naturals de salut estan en detriment, respecte el sistema al·lopàtic que es practica als centres de salut regionals. Aquest fet implica un increment dels costos de salut per als habitants de MKP.

També com els més grans ens expliquen, s'està perdent la gestió tradicional de l'ecosistema a través de les àrees sagrades, ja que les habitants més joves no respecten les normes ecològiques $\mathrm{i}$ culturals que hi ha en aquestes àrees. La pressió econòmica del mercat incentiva a la recol.lecció no sostenible, fet que pot

\footnotetext{
${ }^{20}$ Horitzó temporal fixat per veure els principals canvis a MKP. Per determinar el període d'anàlisi ens hem basat amb informació de la gent més gran i amb una revisió històrica dels events a MKP, que ens permeten afirmar que en els darrers 50 anys es donen els principals canvis a MKP.
} 


\section{perifèria}

Número 7, diciembre 2007

www.periferia.name

posar en perill la sustentabilitat cultural i ecològica de la zona. Com es pot veure en el següent mapa tenim delimitades cinc àrees sagrades a karandamalai, àrees que en la gestió local de l'ecosistema s'utilitzaven com a nuclis de preservació de la biodiversitat en els quals no es poden recol-lectar plantes, tallar arbres, ni pasdtura per aniumals, ja que tenen usos rituals i per tant sagrats (com l'àrea sagrada del Temple de la deïtat local Ayyanar). Actualment el compliment de les normes tradicionals de les àrees sagrades (sacred grooves) estan en detriment, degut a la pressió del mercat i la manca d'alternatives de subsistència.

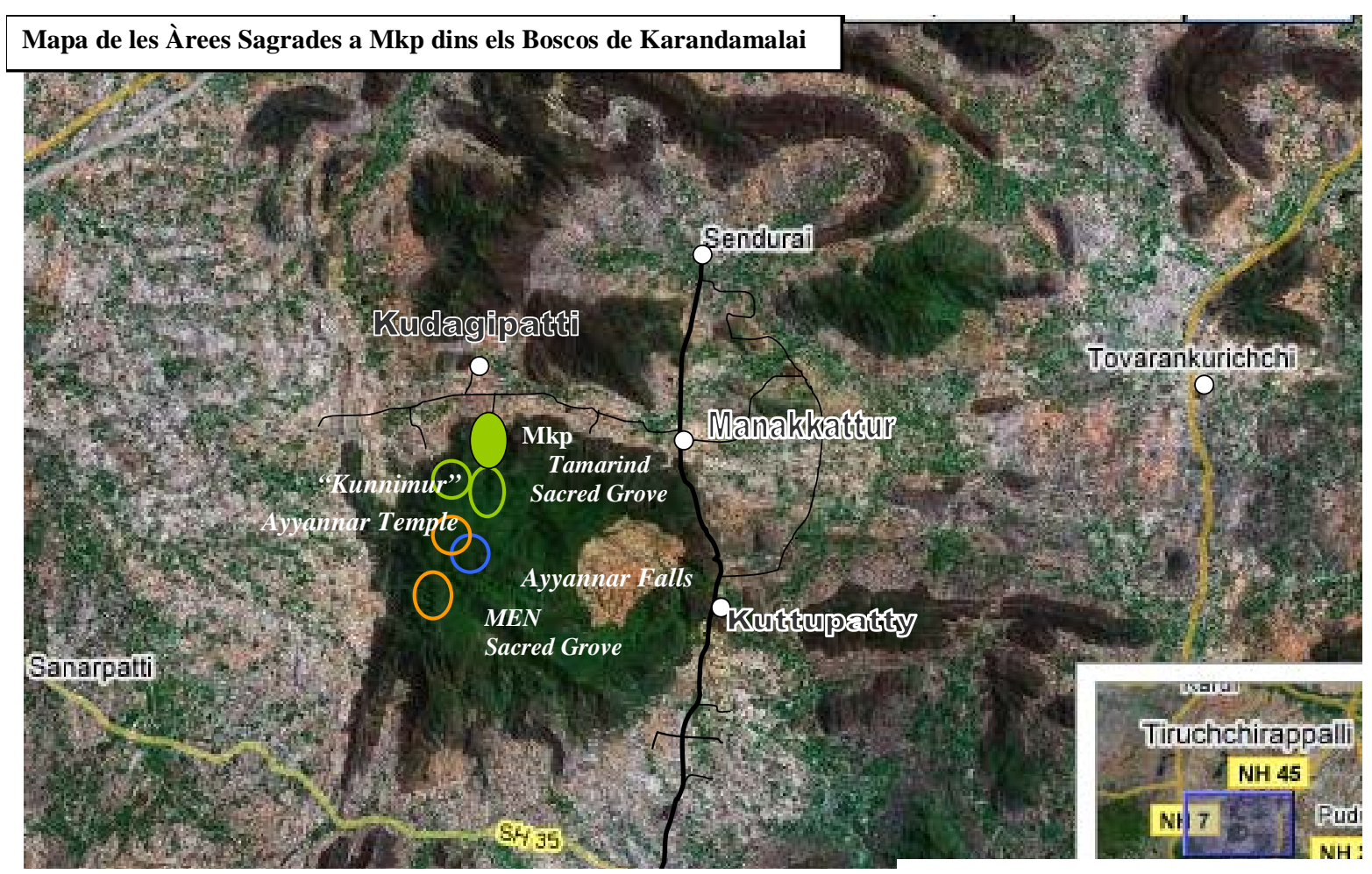

II-Iustració 10. Mapa de les Àrees Sagrades als Boscos de Karandamalai segons informants de MKP Font: Elaboració pròpia amb dades del treball de camp a partir de google maps

Un altre aspecte interessant, i que ens mostra el dinamisme del coneixement ecològic local, és la introducció de nous coneixements i usos de certes espècies de plantes medicinals a MKP. Segons ens expliquen diferents informants majors de 45 anys, hi ha certes espècies que no s'utilitzaven i ara es recullen per comercialitzarles, com per exemple Avaram (Cassia auriculata). Aquesta espècie no es coneixia ni es recollia a MKP abans de l'entrada del mercat, tot i que estava disponible als 


\section{perifèria}

Número 7, diciembre 2007

www. periferia. name

boscos de Karandamalai. El cas de l'arbre de Neem (Azadirachta indica) és també curiós, ja que a MKP i a moltes parts de la India, s'utilitzava per prevenir insectes i com a desinfectant, però amb l'entrada del mercat es van introduir usos cosmètics (per fer sabó i crema anti edat).

Un cop vistos els canvis culturals ocorreguts a través de la introducció del mercat de plantes medicinals a MKP, veiem quin paper hi juga la ONGD CCD i la cooperativa GMCL. Tot i que el CCD també pot fomentar la sobreexplotació del medi ja que es recullen importants volums de plantes medicinals, hem de tenir present que en termes culturals també es realitzen capacitacions per a la recollida sostenible i es lluita perquè no es perdi el sistema tradicional de salut Siddha, tot potenciant-ne el seu ús.

Finalment com enunciàvem en els antecedents teòrics un punt clau dins el canvi paradigmàtic de la sustentabilitat, és captar la visió local del futur per saber quin desenvolupament local es vol. Diferents informats de MKP ens expliquen que la recollida i venda de plantes medicinals és una activitat precària i si tinguessin una feina alternativa deixarien de comercialitzar les plantes, encara que seguirien recollint-les per l'autoconsum.

Tot i la breu estada de camp i les limitacions que això comporta a nivell cultural, pensem que els factors culturals i en concret la gestió de l'ecosistema per part de les comunitats rurals en base al seu coneixement local, és el punt clau que aporta la sustentabilitat.

\section{Dimensió Ecològica}

Tot i que aquest no és el meu camp, intentaré fer una primera aproximació als indicadors tendencials de la sustentabilitat ecològica en la recollida de plantes medicinals. Cal dir que la ONGD CCD en col·laboració amb ATREE ${ }^{21}$, estan duent a terme en aquests moments un monitoratge de tots els recursos naturals dels boscos de Karandamalai. Aquest monitoratge podria ser de gran utilitat per veure l'evolució de les diferents espècies animals i vegetals. El monitoratge també pot

\footnotetext{
${ }^{21}$ Ashoka Trust for Research in Ecology and Environment <http://www. atree.org $>$.
} 


\section{perifèria}

Número 7, diciembre 2007

www. periferia. name

ajudar a descobrir els patrons insostenibles de recollida de plantes medicinals i establir així mesures per a la recuperació dels boscos.

Com es pot deduir de l'explicació fins al moment, la pressió que realitzen els grups de recollida de plantes medicinals sobre l'ecosistema és significativa. Podem afirmar que hi ha una clara sobreexplotació dels recursos especialment en algunes espècies de plantes medicinals. A nivell evolutiu el fet que cinc anys enrere totes les espècies estiguessin disponibles durant tot l'any a Karandamalai, i que ara ja s'hagi d'anar a altres muntanyes a recollir-les, denota aquesta sobreexplotació. Segons diversos informants gairebé totes les espècies comercialitzades estan decreixent en disponibilitat a Karandamalai. Les espècies més malmeses són: Avaram (Cassia auriculata) i Usilai (Albizia amara).

Les principals causes d'aquesta sobreexplotació són la recollida massiva i la no aplicació de les pràctiques sostenibles fomentades pel CCD. Aquesta sobreexplotació més la manca de pluja, provoquen que en els darrers anys l'orografia de Karandamalai hagi canviat, amb una progressiva desertització.

Segons ens expliquen diversos informants i especialistes botànics de la ONGD CCD, la qualitat de les plantes medicinals a Karandamalai segueix sent bona i amb una gran biodiversitat, hi ha més de 300 espècies de plantes medicinals. Els criteris per avaluar la qualitat de les plantes recollides són el tamany, les plagues i malalties, la puresa de les plantes (quantitat d'aigua) i el procés d'assecament.

Les plantes que arriben al centre de Manakkattur són de primera qualitat, encara que en els darrers anys, també es troben amb plantes massa petites. De moment no es té consciència de plagues ni malalties en la flora medicinal a Karandamalai, per tant podem entreveure que la capacitat d'amortització de l'ecosistema encara és sòlida.

Donades aquestes característiques podem dir de manera prudent, que la recollida de plantes medicinals a MKP és insostenible a nivell ecològic, ja que no creiem que en un futur les pràctiques sostenibles de recollida promogudes per al CCD, siguin suficients per evitar la sobreexplotació que des de fa ja molts anys, està provocada per la mercantilització de les plantes medicinals a Karandamalai. 


\section{perifèria}

Número 7, diciembre 2007

www. periferia.name

\section{Primeres Conclusions}

Com hem vist MKP és un poble Valaiyar que depèn totalment dels recursos del bosc i de l'agricultura per a la seva supervivència. La principal font d'ingrés econòmic al poble és la recollida i comercialització de plantes medicinals, seguit de la recollida de fruits com tamarinde $\mathrm{i}$ de les activitats de cultiu. Com es pot veure MKP ha sofert importants canvis ecològics i econòmics en els darrers 50 anys. La manca de pluja i la mercantilització dels productes del bosc posen en dubte la sustentabilitat de les plantes medicinals a Karandamalai.

En primer lloc cal valorar l'anàlisi de la sustentabilitat que presentem, ja que encara estem en una primera fase de la investigació i no podem donar conclusions tancades, sinó més aviat tendències que ens permeten avaluar quins indicadors podem utilitzar en la sustentabilitat econòmica, social, cultural i ecològica.

Comparant el sistema de mercat i el sistema cooperatiu en la comercialització de plantes medicinals a MKP, podem veure diferències importants. EI CCD a través de GMCL aporta una estabilitat de preu i demanda, i dóna una certa autonomia de gestió respecte al mercat. Tot i això es segueix mantenint una dependència comercial important amb els clients finals de les plantes medicinals, seguint el patró del mercat.

A nivell social el $75 \%$ dels recol-lectors de MKP comercialitzen a través de GMCL, mentre que el $25 \%$ restant ho fan a través del mercat. Tot i aquesta alta participació la major part dels recol-lectors no prenen decisions en el grup, sinó que només hi comercialitzen reproduint un patró clientelar i no cooperatiu. També hem vist com els principals promotors i beneficiaris de la comercialització per GMCL a MKP són la família de l'alcalde i altres famílies amb un nivell d'ingressos relativament superior, seguint la tesi de Breton, 2001.

Un altre punt important és la revalorització cultural que promou el CCD, per tal de fomentar el sistema tradicional de salut. Tot i els seus esforços el sistema tradicional de salut a MKP s'està perdent a favor del sistema al-lopàtic. És interessant veure com el coneixement ecològic local es va resignificant amb la introducció de de nous coneixements introduïts pel mercat. Certes pràctiques 


\section{perifèria}

Número 7, diciembre 2007

www. periferia.name

tradicionals de gestió de l'ecosistema com és el sistema d'àrees sagrades, s'estan perdent per la pressió intensiva que marca el mercat.

A nivell ecològic destaquem que la major part de plantes medicinals comercialitzades a MKP, tant en el sistema de mercat com en el sistema cooperatiu, estan despoblant-se paulatinament, fet que posa en dubte la sustentabilitat de certes espècies a llarg termini.

Aquest primer anàlisi tot i tenir certes mancances pretén fer una primera aproximació a la sustentabilitat, i crec que les aportacions metodològiques a nivell social i cultural ens poden ajudar a reflexionar sobre el món de la cooperació internacional i sobre el mercat de productes naturals que des d'occident consumim. No sabem quines implicacions econòmiques, socials i culturals per als pobles recollectors, té el nostre consum de productes naturals, tampoc sabem les conseqüències ecològiques sobre el medi degut a la sobreexplotació dels recursos. Esperem que l'article pugui contribuir a aquesta reflexió posant de manifest la necessitat de conceptualitzar les relacions entre societats i el seu ecosistema (natura-cultura) des d'un altre punt de vista crític i integrador, deixant enrere els pressupostos economicistes que han marcat la cooperació internacional fins al moment.

\section{Bibliografia}

Apffel-Marglin and Marglin (1990). Dominating Knowledge: Development, Culture, and Resistance Stephen Marglin, eds. Oxford: Clarendon Press

Baridotti R [et al.] (1994). Women, the environment and sustainable development : towards a theoretical synthesis. London: Zed Books

Bentley J. W. i Rodríguez G. (2001). Honduran Folk Entomology. Current Anthropology, volume 42 (2001)

Bonfill Batalla, G (1982). El etnodesarrollo: sus premisas jurídicas, políticas y de Organización, en F.Rojas Aravena (comp), América Latina: etnodesarrollo y etnosuicidio, San José de Costa Rica, FLACSO pp. 131-145.

Breton, V. , García, F, Roca, A (1999). Los límites del desarrollo. Barcelona: Icaria Editorial.

Bretón, V. (2001). Cooperación al desarrollo y demandas étnicas en los Andes ecuatorianos. Flacso Ecuador

Breton, V. (2005). Capital Social y Etnodesarrollo en los Andes. Centro Andino de 


\section{perifèria}

Número 7, diciembre 2007

www. periferia. name

Acción Popular -CAAP- Ecuador.

Bryant, RL (1992). Political Ecology. An emerging Research Agenda in Third World Studies. Political geography 11(1), pp. 12-36.

Cernea, M.M (1995). Social organisation and Development Anthropology. Human Action 54(3), pp.340-352.

Cardoso de Oliveira (1992) Etnicidad y estructura social México : CIESAS

Escobar, Arturo (1991). "Anthropology and the Development Encounter: The Making and marketing of Development Anthropology", American Ethnologist, Vol.18, no 4, pp.658-682.

Escobar, Arturo (1995). Encountering Development. The Making and Unmaking of the Third World. Princeton University

Escobar, A. (1998). Whose Knowledge, Whose Nature?, Journal of Political Ecology Vol. 5 .

Escobar, A. (1998) "The Problem of nature" Revisted: History and Anthropology? Current Anthropology, Vol.39, №3, pp. 385-338. University Chicago Press.

Escobar, Arturo (2000) El lugar de la naturaleza y la naturaleza del lugar: ¿globalización o postdesarrollo? Viola, A (2000: 169-217). Barcelona: Ed.Paidós.

Esteva, G. (1993). Development, en W.Sachs (ed) The Development Dictionary: A Guide to knowledge as Power. Londres: Zed Books, 1999 p.6-25

Fergusson, J. (1990). The Anti-politics machine "Development" Depoliticization, and Bureocratic Power inLesotho. Cambridge: Cambridge University Press.

Grueso, Rosero i Escobar (1998). The Process of Black Community Organizing in the Southern Pacific Coast Region of Colombia. Cultures of politics/politics of cultures. J ournal of Latin American Studies (2005), 37: 285-310.

Etkin, N. (2000). Local Knowledge of Biotic Diversity and its Conservation in Rural Hausaland, Northern Nigeria. University of Hawaii.

Godoy, R, Reyes-García, V. Byron, E; R.Leonard, W; Vadez, V (2005). The Effect of Market Economies on the Well-Being of Indigenous Peoples and on Their Use of Renewable Natural Resources, The Annual Review of Anthropology, Vol. 34, Pages 121-138

Horowitz, M.M. ( 1996). Thoughts on Development Anthropology after twenty years. En E.F. Moran (comp) pp.325-351,

Kuhnlein, H.V. i Turner, N.J. (1991). Traditional Plant foods of Canadian indigenous peoples. Nutrition, botany and use. Philadephia (USA) Volume 8.Gordon and Bre.

Sachs, W (1993). Global Ecology and the shadow of development, en W. Sachs (ed.) Global Ecology: a new arena of political conflict. Londres: Zed books.

Sharachchandra L. Jagannath Rao (1996). Whose Co-operatives and Whose Produce? The Case of LAMPS in Karnataka. Rediscovering Co-operation, November 19-21. National Seminar. Institute of Rural Management Anand (Bangalore-India) 


\section{perifèria}

Número 7, diciembre 2007

www. periferia.name

Shiva, V i Mies, M (1998). La praxis del Ecofeminismo: Biotecnologia, consumo, reproducción. Barcelona: Icaria editorial.

Shiva, V. (1989). Staying alive: Women, Ecology and Development. London Zed Books.

Shiva, V. (1993). Farmers' rights. Biodiversity and international Threaties. Economical and Political Weekly, 3 abril, pp-555-560.

Shiva, V. (2005). Earth democracy. Justice, Sustainability and Peace. South End Press Cambridge .

Singh V. i Jain A.P. (2003). Ethnobotany and medical plants of India and Nepal. Reprint J odhpur Scentific. India

Sinha, A., i Bawa K. S. (2002) Harvesting techniques, hemiparasites and fruit production in two non-timber forest tree species in South India. Forest Ecology and Management 168: 289-300 Boston.

Stavenhagen, R. (2001). La Cuestión étnica, México, D.F.: El Colegio de México.

Uma S, Ganeshaiah, M. Nageswara R., N.A. Aravind (1996). “Ecological Consequences of Forest Use: From Genes to Ecosystem. A Case Study in the Biligiri Rangaswamy Temple Wildlife Sanctuary, South India", Economic Botany 50 (3): 252-279.

Viola, Andreu (2000). Antropología del desarrollo. Teorías y estudios etnográficos en América Latina. Barcelona: Ed. Paidós

World comison of development (1987). Our Common Future. Oxford: Oxford University Press

\section{Bibliografia específica del cas d'estudi}

Covenant Centre for Development (1999, 2001, 2003 i 2005-2006). Annual reports. Madurai (India).

Covenant Centre for Development (2005) Medicinal Plants -From Local Resource To Local-Community Enterprise. Madurai (India).

CCD i ATREE (2006). Socio economical Survey on Karandamalai and Perumalai Hills". Bangalore (India).

P. Saravanan (2006). Agro-biodiversity of hilly regions: Livelihood options and conservation. Workshop on Sharp projects on Environment. Centre for plants, people and ecosystems (CPPE), Chennai (India).

Van Loon, Narasimhan, et al. (2005). Annual report on policy development to support bio-diversity within agricultural systems of hilly regions of north and south India (April 2004-March 2005) Shastri Applied research project (SHARP). Centre for plants, people and ecosystems (CPPE), Chennai (Índia).

\section{Webs citades}

Covenant Centre for Development (CCD)

$<$ www.ccd.org.in> 


\section{perifèria}

Número 7, diciembre 2007

www.periferia.name

Ashoka trust for Research in Ecology and Environment (ATREE)

$<$ www.atree.org >

World Bank Development Comission (2007), The goals of the millenium 2007

<http://www.un.org/spanish/millenniumgoals/report2007/mdgreport2007r2.pdf>

Tamil Nadu Public service Comission (2001), Annexure II: 115-12-2a

<www.tn.gov.in/department/mbclist.htm> 